\title{
OFF-GRID, COMMUNITY-BASED DENDROTHERMAL POWER GENERATION: A VAALE OPTION FOR CLEAN DEVELOPMENT MECHANISM
}

\author{
EYK Lokupitiya and B:MS Batagoda \\ Environmental Economics anc Global Affairs Division \\ Ministry of Environment and Natura: Resources, Battaramulla
}

Sri Lanka has taken various measures to implement the United Nations Framework Convention on Climate Change within the country. Clean development mechanism (CDM) provides a framework for participation of developing countries in mitigating climatic effects. In CDM, a developed country will implement and finance a project that reduces or mitigates greenhouse gas (carbon dioxide) emissions in a developing country, for which the developed country party would get Certified Emission Reductions (CERs), certifying the emissions reduced from the CDM project. Such a CDM project would help the developing country in achieving its sustainable development goals, and the country can also profit by selling any carbon avoided by the CDM project to the developed country party.

In Sri Lanka, power sector is a potential sector for CDM, due to high carbon emissions associated with thermal power generation. Since Sri Lanka has almost reached its maximum hydropower potential, the country needs to consider laving more thermal and renewable energy options in the power sector. One potential, relatively cheap renewable option is dendrothermal power generation. Power generation using biomass collected from energy plantations could be considered as a suitable renewable option, especially in remote areas, where power supply from the national grid is not easy. Such energy plantations can be successfully grown and maintained by the communities in rural Sri Lanka, and it has a high potential as a means of poverty eradication and employment generation in those areas. Energy plantations also improve soil quality and nutrient cycling within the ecosystem.

Dendrothermal power generation is considered carbic neutral, as carbon emitted during power generation is absorbed by the energy plantations in photosynthesis. If a certain percentage of the planned thermal power (coal) generation in future cin be replaced with dendrothermal power generation, the country can profit by selling the avoided carbon in shifting to dendrothermal power. Therefore dendrothermal power generation sstisfies the criteria relevant to CDM. This study economically analyses the feasibility of havir $\&$ off-grid dendrothermal power generation as a potential CDM option, while evaluating socio-economic and other benefits associated with it.

The study showed that the unit cost of dendrothermil power generation (US cts. 4.68) is slightly higher than that of coal (US cts. 4.34), but the country can significantly profit if the avoided carbon is sold at a reasonable price. Hence the study clearly shows that dendrothermal power generation is a viable option for CDM. 